\title{
Chapter 12 \\ Gender Differences in Parental Well-being After Separation: Does Shared Parenting Matter?
}

\author{
Katja Köppen, Michaela Kreyenfeld, and Heike Trappe
}

\section{Introduction}

Mothers and fathers face "gendered realities" after union dissolution. Mothers usually continue to live with their children, and thus have to juggle work and parental responsibilities. Moreover, mothers typically experience a significant drop in (equivalent) household income in the aftermath of separation and divorce (Andreß and Bröckel 2007; Bayaz-Ozturk et al. 2018), which is reflected in a decline in their satisfaction with their financial situation (Leopold and Kalmijn 2016). In contrast, the well-being of fathers is more strongly affected by their reduced opportunities to see their children and to interact with them on a regular basis (Huß and Pollmann-Schult 2018). While the economic well-being of fathers does not, on average, decline as much as that of mothers, fathers commonly report substantial drops in satisfaction with family life when they separate (Leopold 2018). Thus, these gendered realities after separation and divorce are mirrored in gendered patterns of well-being. However, recent changes in gender role attitudes and fathers' behaviour suggest that a change

\footnotetext{
K. Köppen $(\square)$

University of Rostock, Rostock, Germany

e-mail: katja.koeppen@uni-rostock.de

M. Kreyenfeld

Hertie School, Berlin, Germany

e-mail: kreyenfeld@hertie-school.org

H. Trappe

Institut für Soziologie und Demographie, Universität Rostock, Rostock, Mecklenburg-Vorpommern, Germany

e-mail: heike.trappe@uni-rostock.de
} 
is occurring. Fathers have become more active in the upbringing of their children. In addition, a growing percentage of separated parents are practising "shared parenting".

Shared parenting is on the rise in many European countries (Smyth 2017; Steinbach 2019). Germany has been a laggard in this trend, as only about 5\% of separated parents with minor children in Germany practise shared parenting arrangements (Kindler and Walper 2016; Walper 2016). Nevertheless, there has been a lively scholarly and public discussion on the "Wechselmodell" in Germany (Sünderhauf 2013; Walper 2016). In particular, the question of whether (equally) shared parenting should be integrated into the legal framework as the standard physical custody arrangement is being debated. Those who favour making (equally) shared parenting the default option typically argue that this change in the law would be a logical response to the increased involvement of fathers in childrearing, while those who oppose such a change generally counter that German family patterns are still traditional, and that it would be premature to define shared parenting as the default model.

Child well-being is an important dimension in the debate on shared parenting. There is a large body of existing literature on the effects of parental separation on the emotional and the economic well-being of children and adolescents (Härkönen et al. 2017; Lee and McLanahan 2015; McLanahan et al. 2013; Walper and Beckh 2006; Walper et al. 2015). For example, a number of studies have looked at how child well-being is affected by the frequency of contact and the quality of the relationship with the non-resident parent (Amato and Rezac 1994; Kalmijn 2016; Poortman 2018). Recent research has examined more specifically the well-being of children involved in shared parenting arrangements (Bauserman 2002; Beckmeyer et al. 2014; Bergström et al. 2015; Braver and Votruba 2018; Nielsen 2018; Steinbach 2019). These studies have suggested that shared parenting can have positive effects on the well-being of children, provided the relationship between the ex-partners is characterised by low levels of conflict (ibid.).

While child well-being has been in the focus of a number of studies, less is known about how shared parenting relates to parental well-being. This study seeks to close part of this research gap by examining how practising shared parenting affects the well-being of fathers and mothers after separation and divorce. We analyse two spheres of life: namely, satisfaction with family life and satisfaction with the financial situation of the household. Our analysis is based on 10 years of longitudinal data from the German Family Panel (pairfam). Fathers and mothers are included, regardless of whether they were married or cohabiting or whether they had ever lived with the other parent. We investigate how separation affected mothers and fathers' well-being. For the group of separated parents, we examine whether practising shared parenting affected their well-being after separation. We add to the literature in the following ways. First, our analysis provides nuanced evidence on

\footnotetext{
${ }^{1}$ We use the term "shared parenting" in this chapter. Apart from "shared parenting", "joint parenting", "joint physical custody", "shared residence", and "shared residential custody" have been used to describe these arrangements in the literature. In the German context, "Wechselmodell" or "geteilte Betreuung" are often used interchangeably for the same arrangements (Schumann 2018). "Umgang" is a legally defined term in German that refers to the non-resident parent seeing the child on a regular basis. Some scholars have argued that "shared parenting" may be captured by the German legal concept of "erweiterter Umgang" (Henneman 2017).
} 
parental well-being by examining different spheres of life satisfaction. Second, we exploit a recent set of rich longitudinal data. While there is a large body of longitudinal research on life satisfaction, less is known about parents' well-being after separation. Third, our study can be added to the small number of studies that have examined the relationship between shared residence and parental well-being in the German context.

\section{Institutional Context, Prior Research, and Hypotheses}

\section{Institutional Context}

In Germany, as in many other European countries, the divorce rate has risen in recent decades. Although the divorce rate has decreased slightly since 2004, the current level suggests that every third marriage in Germany is likely to end in divorce (Statistisches Bundesamt 2018a). In about half of all divorces, children of minor age are involved (ibid.). There are no official statistics on the separation rates of nonmarital unions with children, but evidence from social science surveys suggests that the risk of separation is higher among unmarried than among married couples (Schnor 2014). In the large majority of cases, children continue to reside with their mother after a separation. This is evident from the small share of single fathers reported in the official statistics. About $90 \%$ of lone parents are women (Statistisches Bundesamt 2018b). The prevalence of shared parenting arrangements is not covered in the official statistics. Estimates based on social science surveys by Kindler and Walper (2016: 821) and Walper (2016: 124) indicate that in Germany, only about $5 \%$ of all parents with minor children practice shared parenting after a separation. A government-initiated survey conducted among separated parents in 2016 and 2017 reported substantially higher values of around 15\% (Institut für Demoskopie Allensbach 2017), and found that another $17 \%$ of these parents would consider such an arrangement in the future (ibid.). However, the survey also found that around one-third of the separated parents had never heard of shared parenting (Wechselmodell) (ibid.: 24). As shared parenting is still an ill-defined concept in Germany, estimates of how common such arrangements are seem to be very sensitive to the phrasing of the question. However, regardless of which operational definition is used, the estimates clearly show that the prevalence of shared parenting in Germany is well below the levels that are generally reported in countries such as the Netherlands, Sweden, Norway, and Belgium, where the percentage of separated parents who practice shared parenting ranges from $20 \%$ to $40 \%$ (Smyth 2017; Steinbach 2019).

Shared parenting is not yet legally defined in the German system. German family law regulates visitation rights (Umgangsrecht), based on the assumption that the child lives with one resident parent, while the non-resident parent has the right to see the child on a regular basis. The registration law (Melderecht) stipulates that the child can be registered with the local authorities at only one main place of residence. The parent with whom the child is registered receives the child benefits (Ruetten 2016). As child benefits can only be collected by the resident parent, this area of 
family law ignores the possibility of shared parenting. Other parts of the legal regime are less restrictive, and acknowledge shared parenting. This is, for example, the case for social welfare regulations, which stipulate that child supplements are allocated according to the number of overnight stays the child has at each parent's residence. Furthermore, the non-resident parent is not legally required to pay child alimony if the child lives at the mother's and the father's residences for equal amounts of times (Dethloff and Kaesling 2018). A particularity of the German system is that it provides for a sharp distinction between legal and physical custody. Legal custody (Sorgerecht) confers on a parent the rights and duties associated with making important decisions in the child's life, such as decisions about the child's education or medical care. Joint legal custody has become the default arrangement for divorced parents since 1998 (Dethloff 2015). Unmarried fathers have the legal right to apply for joint legal custody (ibid.). While joint legal custody is the standard legal custody arrangement when parents separate and divorce, there is considerable controversy surrounding the question of whether shared parenting should be made the default physical custody arrangement in the German system.

\section{Prior Research and Theoretical Considerations}

A large body of research has documented that separation and divorce reduces wellbeing (Clark et al. 2008; Diener 2009; Lucas 2007). As separation and divorce are often anticipated and preceded by partnership conflict, the life satisfaction levels of the partners tend to decline before the divorce or separation, and usually do not recover until several years later. Clark et al. (2008), using data from the German Socio-Economic Panel, found that the life satisfaction levels of men recover from divorce more quickly than those of women. Leopold (2018) confirmed this finding, while adding that men tend to experience a greater decrease in life satisfaction around the time of divorce than women. Leopold (2018) also examined other life course domains. His results indicated that between the ex-partners, there are large gender differences in the decline in household income, but only modest differences in levels of satisfaction with the financial situation and the standard of living of the household, and no gender differences in levels of satisfaction with health. Although there is a substantial body of research on life satisfaction levels based on German panel data, most of these studies only included divorcees, while leaving out the large and growing share of the separated population who were in unmarried unions. Furthermore, many of these studies were rather general, and did not address the particular situations of parents, or the "gendered realities" mothers and fathers are subject to after union dissolution.

The gendered realities after separation are closely linked to the division of paid and unpaid work that existed before these unions were dissolved (Leopold and Kalmijn 2016). In societies in which gendered family models are prevalent - i.e., the man is the main breadwinner while the woman works part-time and is in charge of the bulk of the housework and the childcare - mothers face a particularly high 
risk of experiencing a decline in household income in the wake of a separation. The economic costs of union dissolution usually fall more heavily on women than on men because mothers often have lower earnings than fathers, and are more restricted in their labour market opportunities due to their fragmented work careers after entering parenthood (Bröckel and Andreß 2015). The incompatibility of work and family life can also limit the ability of mothers to expand their employment activities after a separation (van Damme et al. 2009). Thus, compared to men, women face greater poverty risks after separation or divorce, and are more likely to be dependent on public transfers (Andreß and Bröckel 2007; Bröckel and Andreß 2015; Geisler and Kreyenfeld 2019; Popova and Navicke 2019). In contrast, men, and especially fathers, tend to experience larger declines in immaterial domains of life satisfaction than women; e.g., in the domains of health satisfaction and mental health (Biotteau et al. 2019; Leopold 2018; Yuan 2016), emotional well-being (Kessler 2018), and satisfaction with family life (Huß and Pollmann-Schult 2018; Leopold 2018; Leopold and Kalmijn 2016). Fathers' diminished levels of emotional and family-related well-being appear to be largely attributable to their reduced opportunities to see their children and to interact with them on a regular basis (Grätz 2017), particularly if the children continue to live with their mother (Steinbach 2019).

Kessler (2018) has made the intriguing argument that as the gender revolution progresses (Goldscheider et al. 2015), and, correspondingly, women's and men's roles in the public and the private sphere converge, the gendered consequences of separation and divorce on parental well-being will decrease. Although the existing empirical evidence does not support this claim (Kessler 2018; Radenacker in this volume), the underlying theoretical idea is appealing because it assumes that the gendered division of paid and unpaid work before and after parental separation, and the parental care arrangements that support a certain division of labour, will moderate the relationship between parental separation and the gendered realities that follow. Empirical research from the Netherlands has shown that separated parents who were practising shared parenting reported having higher life satisfaction than other parents (van der Heijden et al. 2015), while a study from Belgium found no direct effects of joint physical custody on parents' subjective well-being (Sodermans et al. 2015). Mothers who were practising shared parenting reported having less time pressure than resident mothers, whereas fathers who were practising shared parenting reported having slightly greater time pressure than other fathers (van der Heijden et al. 2016). A recent study based on data from the German micro-census found that the welfare benefits mothers were receiving declined significantly if their children were also living with the other parent (Geisler and Kreyenfeld 2019).

While shared parenting has the potential to improve the well-being of parents after separation, this arrangement has so far been adopted by only a small minority of separated parents in Germany. It should also be stressed that there are factors beyond custody arrangements that affect the lives of separated parents. Re-partnering, (re)-marriage, and the birth of a new child are critical events that can redefine the relationship of separated parents with their children from a previous union, and that can affect the separated parents' well-being (Ivanova and Balbo 2019; Soons et al. 2009). In addition, there are several factors that influence parental well-being that 
are also correlated with shared parenting. Fathers and mothers are not selected randomly into shared parenting. Instead, the choice to practise shared parenting depends on parental resources, as joint residence is more expensive than sole residence (Lettmaier and Dürbeck 2019). In order to practise shared parenting, both parents need to have sufficient housing space and equipment for the children. In addition, separated parents who live apart need to budget for the costs of transporting the children between the parents' residences. It is, therefore, not surprising that shared parenting is more common among highly educated than among less educated parents (Steinbach 2019). This selectivity is particularly pronounced under societal conditions in which joint physical custody is uncommon, as is the case in Germany (Walper 2016).

Following the abovementioned line of thought, we may assume that the gendered realities after separation would be mirrored in gendered differences in well-being. Mothers may experience a greater decline in economic well-being than fathers after separation (Hypothesis 1a). Conversely, levels of satisfaction with family life should decrease more among fathers than among mothers after separation (Hypothesis $1 \mathrm{~b}$ ). Practising shared parenting after separation is assumed to increase mothers' financial well-being, because it tends to improve their employment opportunities, reduce their time pressures, and provide them with a better work-life-balance (Hypothesis 2). Fathers who practise shared parenting are, by contrast, assumed to have a more intense and satisfying relationship with their children, because they are spending relatively long and regular periods of time with their children. Thus, we expect that practising shared parenting has a positive effect on fathers' well-being (Hypothesis 3). However, as choosing to practise shared parenting is not a random event, it is important to account for socio-economic factors that may select parents into shared parenting.

\section{Data, Variables, and Research Strategy}

\section{Data and Analytical Sample}

This chapter uses data from the German Family Panel (pairfam), a multidisciplinary, longitudinal study of partnership and family dynamics in Germany (Brüderl et al. 2019; Huinink et al. 2011). The German Family Panel is an annual survey that includes respondents of the birth cohorts 1971-73, 1981-83, and 1991-93. The first wave was conducted in 2008/09, and the most recent wave available is from 2017/18. In 2009/10, an oversample of eastern German respondents was added to the data (Kreyenfeld et al. 2012). The total number of observations for the ten survey waves, including the oversample, is 75,186 observations for 13,891 subjects. One of the exceptional features of this survey is that it collects detailed monthly partnership histories. Respondents are queried about the start and end dates of all partnerships that had a duration of more than 3 months, including living-apart-together relationships. If children resulted from a relationship, respondents were asked to report the start and end points of the partnership, regardless of its duration. 
We have restricted this investigation to respondents whose first child was aged 17 or younger at the time of the survey. We focus on first-born children in order to simplify the analysis. We have dropped respondents with incomplete birth or partnership histories, as well as respondents whose first child was already aged 18 or older. An individual respondent could contribute several person-years to the data. In our analytical sample, we observe 5,776 subjects over 27,190 person-years. Parts of the analysis are restricted to separated parents. In order to identify whether a respondent was separated from the parent of his/her first-born child, we have combined the respondents' partnership and fertility histories. If the respondent was in a partnership when his/her first child was born, but separated from that partner later on, we assume that the person was a separated parent. Our procedure relies on the assumption that the respondent's partner at the time the child was born was the biological parent. ${ }^{2}$ We observe 550 separated fathers and 1,062 separated mothers in the data. The large difference in the sample sizes of separated fathers and separated mothers can be attributed to the differences in the ages at which women and men experience separation. However, under-coverage of fathers (Joyner et al. 2012) - and especially of separated fathers, given their high levels of attrition following separation - may have also contributed to this gap (Müller and Castiglioni 2015).

\section{Variables}

The two outcome variables are satisfaction with family life and satisfaction with the financial situation of the household. Both variables are measured on a scale that ranges from zero (very dissatisfied) to ten (very satisfied). While satisfaction with family life is surveyed every year, satisfaction with the financial situation of the household was not yet surveyed in the first wave; thus, the sample size for the analysis of this variable is slightly smaller than the sample size for the analysis of satisfaction with family life. Table 12.6 in the appendix provides the sample descriptives. The table shows that satisfaction with family life (mean 8.51 in the total sample) was substantially higher than satisfaction with the financial situation of the household (mean 6.31 in the total sample).

A key independent variable of interest is the duration since the separation from the parent of the first-born child. A few respondents were not in a relationship when their first child was born. In such cases, we assume that separation occurred at the time of childbirth. We include the family status at first birth, distinguishing between married and unmarried respondents. The latter group is further distinguished by whether they were cohabiting or were not living with a partner (denoted

\footnotetext{
${ }^{2}$ The German Family Panel includes information on the filiation of the respondents' biological children to their past partners. We did not, however, refer to this information to verify whether the partner at childbirth was indeed the biological parent of the child, as this information is often missing in the data. We also did not consider whether the respondents re-partnered with the biological parent of their first child, because only a fraction of the respondents separated from and then repartnered with the biological father later in the life course (Bastin 2016).
} 
as "single"). A key variable that depicts changes in the post-separation partnership trajectory is a variable for the current family status. This covariate is time-varying, and distinguishes between respondents who were (a) single, (b) who had a partner (living-apart-together relationship, LAT), (c) who had a partner and were living with their (new) partner (cohabiting), and (d) who were married and living with their partner. Married individuals who were not living with their partner are not considered married here, as some of the respondents may have been separated but not yet officially divorced. We also account for whether the respondent had a (new) child with the current partner. This variable is again time-varying, and indicates whether the respondent has a child with the current partner. The standard control variables are age and gender. We also include a binary variable for region to account for possible differences between East and West Germany. East Germany is defined here as the eastern German states, including Berlin. We also consider the highest level of education. This variable is time-varying, and distinguishes between low (ISCED1997 0-3), medium (ISCED1997 4-6), and high (ISCED1997 7-8) levels. Employment status is also time-varying, and distinguishes between individuals who were employed, unemployed, and not in the labour force (e.g., students, homemakers, or parents taking leave).

The main variable of interest is the parenting arrangement after separation and divorce. There is currently no legal definition of shared parenting. Some researchers have defined shared parenting as an arrangement in which children spend between $25 \%$ and $50 \%$ of their time with each parent (Steinbach 2019). This definition leaves open the question of whether the children in such an arrangement have to stay overnight with both parents. It is also unclear whether shared parenting must involve face-to-face contact with the children. Moreover, this definition does not specify how shared parenting is aligned with the children's activities that take place outside of the time they spend with their parents. Teenage children in particular may spend only a limited share of their time with either of their parents. If we assume that shared parenting is defined by the amount of time children spend with each of their parents, we would ideally draw on time use data to measure the prevalence of shared parenting. The German family panel does not include such information. However, there are two major sources in the data that allow us to reconstruct the place of residence of a given child, and to infer the amount of time the child was spending with each parent. In a first step, we seek to determine whether the child was living with the respondent, the other parent, or in another arrangement. ${ }^{3}$ If the child was not

\footnotetext{
${ }^{3}$ The following categories are distinguished: $1=$ only with the respondent; $2=$ with the respondent, but also alone/in a dwelling shared with others; $3=$ with the respondent and with the other parent, but mostly with the respondent; 4 = with the respondent, but also with the other parent, more or less equally often with the respondent and the other parent; $5=$ with the respondent but also with the other parent, but mostly with the other parent; $6=$ with the respondent, but also with other relatives; $7=$ with the respondent, but also in the child's home; $8=$ with the respondent, but also somewhere else not listed; $9=$ only alone/in a dwelling shared with others; $10=$ only with the other parent; $11=$ only with other relatives; $12=$ only in a children's home; $13=$ only somewhere else not listed.
} 
living with the respondent, we use the survey data to assess how often the parent was seeing the child. If the child was living with the respondent, we attempt to determine how often the other parent was seeing the child. ${ }^{4}$ Based on these two sources of information, we have generated a variable that distinguishes four categories:

- Resident parenting: This category includes respondents who were living with the child and were not practising shared parenting.

- Non-resident parenting: This category includes respondents who were not living with the child and were not practising shared parenting.

- Shared parenting: This category includes respondents who reported that the child was living with the respondent and with the other parent "more or less equally often". It also includes respondents who said that the child was mainly living with them, but was also living with the other parent. Conversely, it also includes respondents who reported that the child was mainly living with the other parent, but was also living with them. Moreover, we include respondents who reported that the non-resident parent was seeing the child every day, and respondents who characterised themselves as a non-resident parent who was seeing the child every day.

- Other: This category includes respondents who reported that the child was in another arrangement, such as living in a relative's home, in his/her own flat, or in a children's home.

Figure 12.1 shows that $12 \%$ of the respondents in the sample were practising shared parenting. ${ }^{5}$ The figure also indicates that shared parenting was socially selective. As expected, we find that respondents who were highly educated and employed, and who thus likely had high earnings, were more likely than other respondents to be practising shared parenting. The findings further indicate that shared parenting was slightly more prevalent in West than in East Germany, and was much more

\footnotetext{
${ }^{4}$ The survey collects information on how often the non-resident parent sees the child. In addition, the resident parent is asked how often the other parent sees the child. The following response categories are distinguished: (1) daily; (2) several times per week; (3) once per week; (4) 1-3 times per month, (5) several times per year; (6) less often; (7) contact broken off; and (8) contact never established (9).

${ }^{5}$ The values are very sensitive to the operational definition of shared parenting. If shared parenting is defined only as those situations in which the child is living "more or less equally often" with both parents, we find that just $3 \%$ of the respondents were practising shared parenting. If we include those respondents who reported that they were "mostly" living with the child, the value increases to $5 \%$. If we include those respondents who see the child daily, the value increases to $12 \%$ (which is the definition adopted in this study, see above). If we also include those respondents who see the child several times per week, the value rises to $20 \%$. If we adopt the latter definition, we find highly significant results for the impact of shared parenting on fathers' satisfaction with family life. However, the effect is not stable to the inclusion of socio-economic covariates. We have also conducted sensitivity analysis for the other operational definitions of shared parenting. The results of this analysis were strongly affected by the very low number of "positive events" in the data, and hardly any of the covariates were found to be significant.
} 


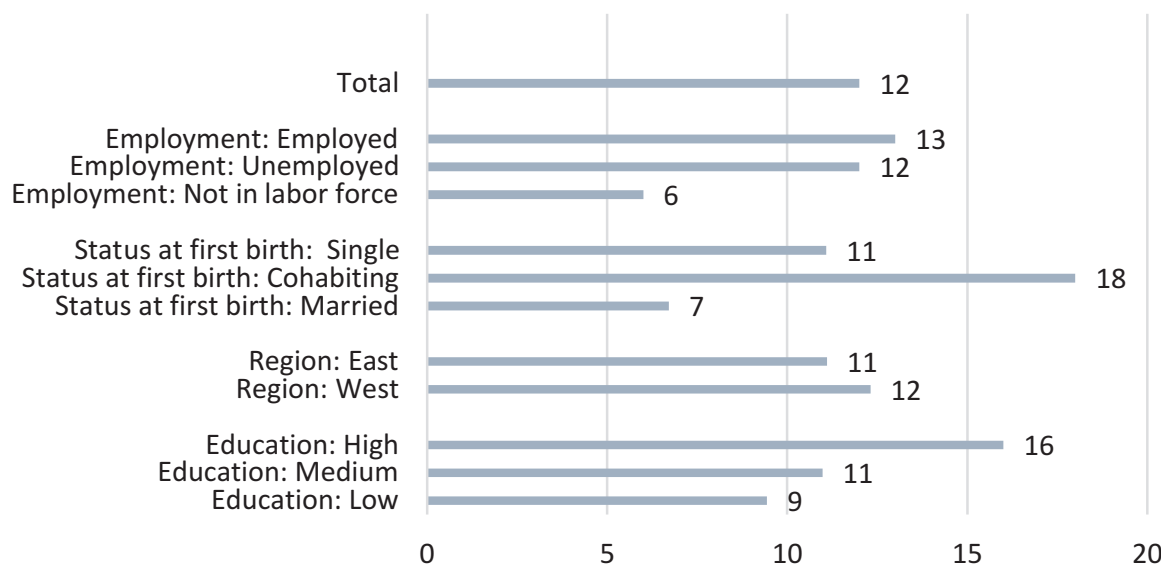

Fig. 12.1\% shared parenting by socio-economic characteristics of separated parents

prevalent among parents who were cohabiting at the first birth than among parents who were previously married.

Table 12.1 reports the distribution of the other control variables for the sample of separated parents (for the full sample, see Table 12.6 in the appendix). The table shows that the sample includes more women than men. As we noted earlier, this gap is largely attributable to the differences between men and women in the ages at birth and separation, but it may also be linked to the under-coverage of separated fathers in the survey. About $40 \%$ of the individuals in the sample are eastern Germans. This high share of eastern Germans is due to the oversampling of eastern Germans in pairfam. The regression analysis accounts for this bias by controlling for region. The data include respondents of the birth cohorts 1971-73, 1981-83, and 1991-93. Thus, the age structure of our respondents was fairly young. The respondents were, on average, 35 years old. It is important that we control for age, given that the respondents we are observing experienced a separation at an early stage of their life course. The sample statistics also reveal gender differences in educational attainment, with the women in the sample being less likely than the men to hold a university degree. Although women in Germany reached parity in higher education in the early 2000s, this pattern does not show up in our data, most likely because we have limited the analysis to parents, and there appears to be a negative educational gradient in women's childlessness. Thus, highly educated women are more likely to remain childless (Bujard 2015). Likewise, we observe stark gender differences in employment patterns. Although women tend to expand their employment activities in anticipation of and after a divorce or separation (Bröckel and Andreß 2015; de Regt et al. 2013; Thielemans and Mortelmans 2019), the share of employed women in our sample is much lower than that of employed men. Among the separated parents in the sample, only a quarter were living in a marital union at first birth, while the majority were either single or living in a non-marital union. We can also see that about $60 \%$ of our sample members (or rather $60 \%$ of the person-years) were already 
12 Gender Differences in Parental Well-being After Separation: Does Shared...

Table 12.1 Sample composition, separated parents, person-years by column percent

\begin{tabular}{|c|c|c|c|c|c|c|}
\hline & \multicolumn{3}{|c|}{$\begin{array}{l}\text { Satisfaction with family } \\
\text { life }\end{array}$} & \multicolumn{3}{|c|}{$\begin{array}{l}\text { Satisfaction with financial } \\
\text { situation }\end{array}$} \\
\hline & Men & Women & Total & Men & Women & Total \\
\hline \multicolumn{7}{|l|}{ Gender } \\
\hline Male & - & - & 0.33 & - & - & 0.33 \\
\hline Female & - & - & 0.67 & - & - & 0.67 \\
\hline \multicolumn{7}{|l|}{ Region } \\
\hline Western Germany & 0.53 & 0.61 & 0.58 & 0.53 & 0.60 & 0.58 \\
\hline Eastern Germany & 0.47 & 0.39 & 0.42 & 0.47 & 0.40 & 0.42 \\
\hline \multicolumn{7}{|l|}{ Duration since separation } \\
\hline $0-1$ years after separation & 0.17 & 0.15 & 0.16 & 0.17 & 0.15 & 0.16 \\
\hline 2-3 years after separation & 0.14 & 0.14 & 0.14 & 0.14 & 0.14 & 0.14 \\
\hline 4-5 years after separation & 0.13 & 0.13 & 0.14 & 0.13 & 0.13 & 0.13 \\
\hline 6-7 years after separation & 0.13 & 0.13 & 0.13 & 0.12 & 0.13 & 0.13 \\
\hline $8-9$ years after separation & 0.13 & 0.13 & 0.13 & 0.12 & 0.13 & 0.12 \\
\hline 10 or more years after separation & 0.30 & 0.32 & 0.31 & 0.32 & 0.32 & 0.32 \\
\hline \multicolumn{7}{|l|}{ Education } \\
\hline Low & 0.11 & 0.20 & 0.17 & 0.10 & 0.19 & 0.16 \\
\hline Medium & 0.63 & 0.61 & 0.62 & 0.63 & 0.61 & 0.62 \\
\hline High & 0.26 & 0.19 & 0.21 & 0.27 & 0.20 & 0.22 \\
\hline \multicolumn{7}{|l|}{ Employment status } \\
\hline Employed & 0.79 & 0.62 & 0.68 & 0.80 & 0.64 & 0.69 \\
\hline Unemployed & 0.12 & 0.12 & 0.12 & 0.11 & 0.11 & 0.11 \\
\hline Not in labour force & 0.08 & 0.25 & 0.19 & 0.08 & 0.24 & 0.19 \\
\hline Missing & 0.01 & 0.01 & 0.01 & 0.01 & 0.01 & 0.01 \\
\hline \multicolumn{7}{|l|}{ Family status at first birth } \\
\hline Married & 0.25 & 0.29 & 0.28 & 0.26 & 0.29 & 0.28 \\
\hline Cohabiting & 0.39 & 0.31 & 0.34 & 0.40 & 0.32 & 0.34 \\
\hline Single & 0.36 & 0.40 & 0.38 & 0.34 & 0.39 & 0.38 \\
\hline \multicolumn{7}{|l|}{ Current family status } \\
\hline Single & 0.35 & 0.37 & 0.36 & 0.36 & 0.37 & 0.36 \\
\hline LAT & 0.12 & 0.20 & 0.17 & 0.12 & 0.19 & 0.17 \\
\hline Cohabiting & 0.23 & 0.19 & 0.21 & 0.23 & 0.20 & 0.21 \\
\hline Married & 0.30 & 0.24 & 0.26 & 0.29 & 0.24 & 0.26 \\
\hline \multicolumn{7}{|l|}{ Child with current partner } \\
\hline Child with current partner & 0.30 & 0.25 & 0.26 & 0.29 & 0.25 & 0.26 \\
\hline No child with current partner & 0.70 & 0.75 & 0.74 & 0.71 & 0.75 & 0.74 \\
\hline \multicolumn{7}{|l|}{ Parenting arrangement } \\
\hline Residence with child & 0.23 & 0.87 & 0.66 & 0.21 & 0.85 & 0.65 \\
\hline Shared parenting & 0.14 & 0.08 & 0.10 & 0.17 & 0.10 & 0.12 \\
\hline Non-resident parent & 0.56 & 0.02 & 0.20 & 0.55 & 0.02 & 0.19 \\
\hline Other & 0.07 & 0.03 & 0.04 & 0.07 & 0.03 & 0.04 \\
\hline
\end{tabular}


Table 12.1 (continued)

\begin{tabular}{|c|c|c|c|c|c|c|}
\hline & \multicolumn{3}{|c|}{$\begin{array}{l}\text { Satisfaction with family } \\
\text { life }\end{array}$} & \multicolumn{3}{|c|}{$\begin{array}{l}\text { Satisfaction with financial } \\
\text { situation }\end{array}$} \\
\hline & Men & Women & Total & Men & Women & Total \\
\hline \multicolumn{7}{|c|}{$\begin{array}{l}\text { Continuous covariates (Mean, std. } \\
\text { error) }\end{array}$} \\
\hline Age (Mean) & 36.69 & 34.81 & 35.43 & 37.19 & 35.20 & 35.85 \\
\hline Age (std. error) & $(0.12)$ & $(0.09)$ & $(0.07)$ & $(0.13)$ & $(0.09)$ & $(0.08)$ \\
\hline Age of child (Mean) & 10.26 & 10.28 & 10.28 & 10.45 & 10.40 & 10.42 \\
\hline Age of child (std. error) & $(0.09)$ & $(0.07)$ & $(0.06)$ & $(0.11)$ & $(0.07)$ & $(0.06)$ \\
\hline Satisfaction (Mean) & 7.65 & 8.05 & 7.91 & 5.42 & 5.30 & 5.34 \\
\hline Satisfaction (std. error) & $(0.05)$ & $(0.03)$ & $(0.03)$ & $(0.06)$ & $(0.04)$ & $(0.04)$ \\
\hline \multicolumn{7}{|l|}{ Sample size } \\
\hline Subjects & 550 & 1062 & 1612 & 437 & 844 & 1281 \\
\hline Person years & 2128 & 4371 & 6499 & 1739 & 3579 & 5318 \\
\hline
\end{tabular}

Notes: Unweighted values

living with a new partner, and that the likelihood of re-partnering did not differ by gender. This latter finding seems to contradict the widely held view that mothers have lower chances of re-partnering than fathers (Ivanova et al. 2013). It appears, however, that women were more likely than men to choose less institutionalised forms of partnerships, such as living-apart-together relationships. About a quarter of the respondents reported that they have a child with their current partner. Again we find that the likelihood of having another child did not vary by gender.

\section{Research Strategy}

The analysis consists of two major parts. In the first part of our analysis, we estimate the effect of separation on satisfaction with family life and satisfaction with the household's financial situation. We do so by using pooled linear regression models to analyse the total sample of mothers and fathers (including separated and nonseparated parents). The results are reported as unstandardized coefficients. We treat the dependent variables as cardinal, and thus assume that the 11 satisfaction categories carry a meaning. It has been shown that assuming cardinality as opposed to ordinality is largely irrelevant for the results (Ferrer-i-Carbonell and Frijters 2004). As subjects may have entered the analysis several times, we have generated robust standard errors that account for the multiple occurrence of the respondents in the sample. Model 1 only includes an indicator for separation (as well as region to account for the oversampling of East Germans). Model 2 controls for the major socio-economic control variables, such as education, employment, age, age of child, and family status at first birth. Since unobserved characteristics may still bias our investigations, we estimate another model (Model 3) that employs fixed-effects modelling that accounts for time-constant individual heterogeneity (Allison 2009). 
In the fixed-effects model, we only control for traits that vary substantially across time: namely, age, age of child, and employment status. We also insert dummy variables for calendar year, which is generally recommended for fixed-effects models in order to account for overall trends. We conduct all investigations separately by gender. To better compare the estimates for women and men, we also pool the male and the female sample, and introduce an interaction effect of separation and gender. We insert the categorical variable for "duration since separation" into this specification in order to examine how life satisfaction develops in the aftermath of separation. To make the gender differences easier to gauge, we display the results in a graph as predicted values, along with their $95 \%$ confidence intervals.

The second part of the investigation focuses on separated parents. Specifically, we examine how shared parenting affects satisfaction with family life, and satisfaction with the household's financial situation. The investigation is restricted to the period after separation. We again estimate OLS-regressions. We first estimate a model without socio-economic covariates (Model 1). We then estimate a model that includes the socio-economic controls in order to assess how the association of shared parenting and life satisfaction was affected by the particular characteristics of the parents who opted for shared parenting (Model 2). The final model (Model 3) adopts a fixed-effects modelling approach. Again, all of the analyses are conducted separately by gender, and for the two different spheres of life satisfaction.

\section{Results}

\section{Separation and Parental Life Satisfaction}

Table 12.2 reports the regression results for satisfaction with family life. Model 1 includes the OLS-regression that only controls for whether the respondent is a separated parent. The model shows that fathers' life satisfaction levels decline by 1.05 units after separation. The effect is rather stable to the inclusion of further covariates (Model 2). The fixed-effects model corroborates this finding, showing a negative effect of separation on satisfaction with family life. However, the effect size is slightly smaller in magnitude than in the OLS-regression. The model results for the female sample also show that separation affects satisfaction with family life, but the strength of the parameter is weaker than it is for the male model. The parameter is now only 0.41 .

Table 12.3 reports the regression results for satisfaction with the household's financial situation. The OLS model without the socio-economic controls again shows a strong negative parameter. The level of satisfaction with the household's financial situation drops by about one unit after separation for males. However, the parameter is not stable across specifications. The inclusion of the socio-economic characteristics reduce the parameter to 0.60 . The fixed-effects model reduces the parameter even further, to 0.38 . In the latter model, the parameter is no longer significant. The model results suggest that socio-economic characteristics as well as 


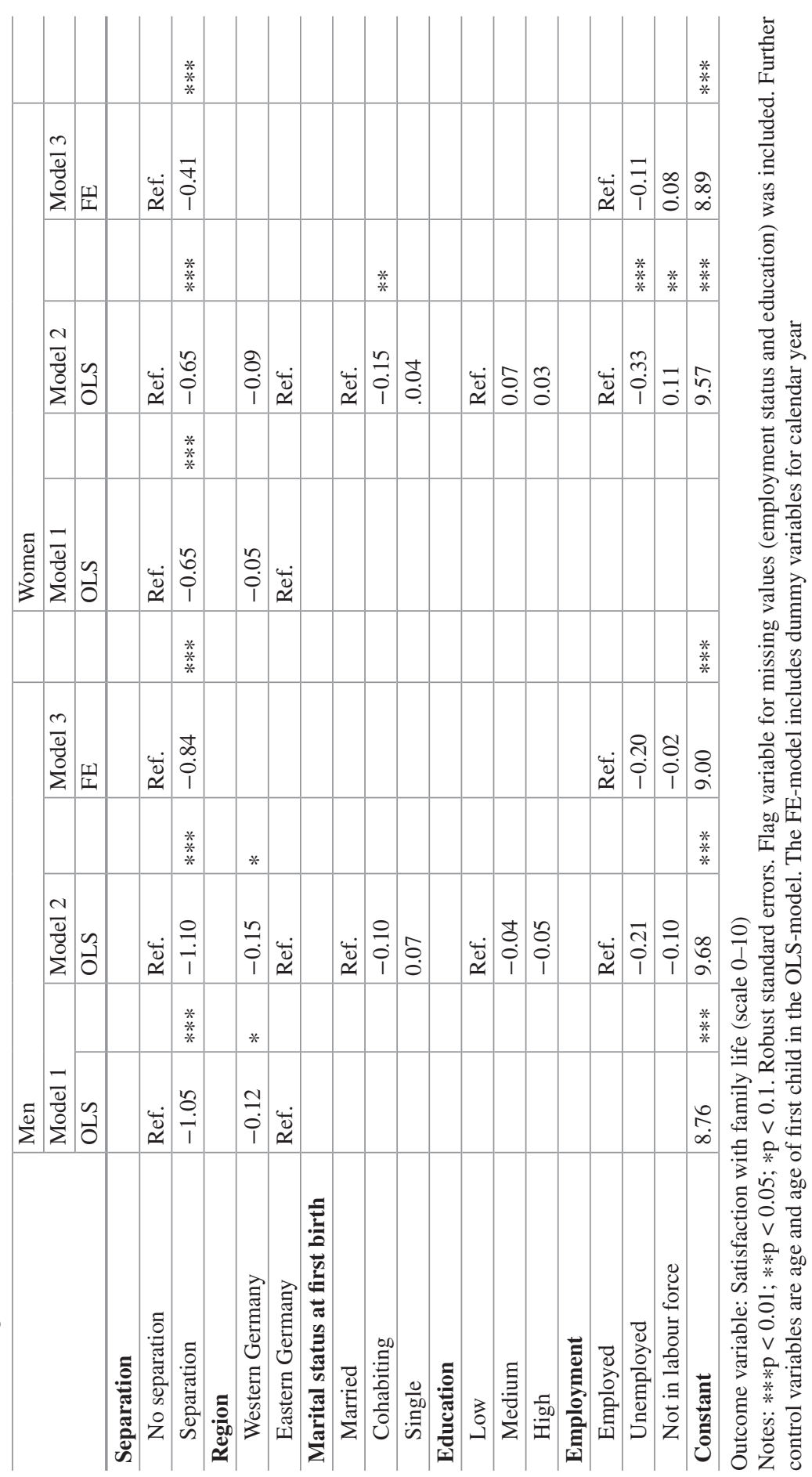




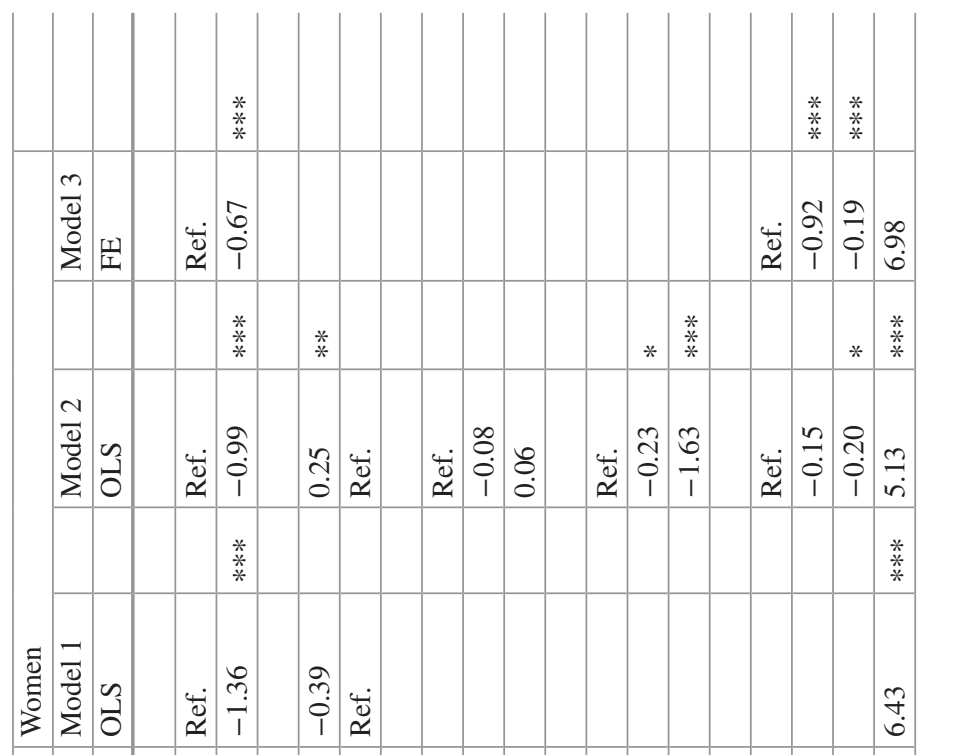

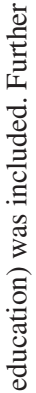

\begin{tabular}{c|c|c|c}
$*$ & $*$ & $*$ \\
$*$ & $*$ & $*$ \\
\hline
\end{tabular}

胥 䒿 䒕 है 离 舟

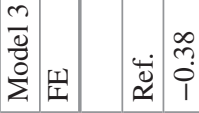

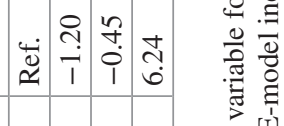

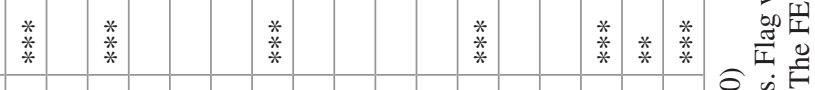

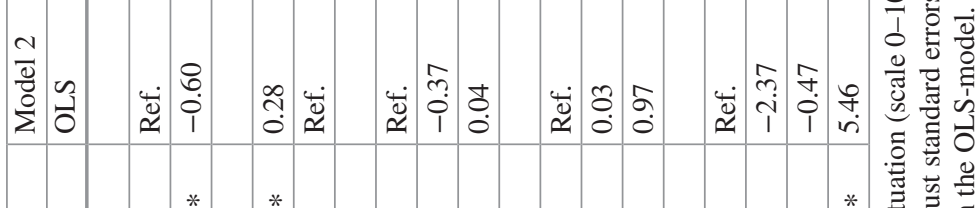
\begin{tabular}{l|l|l}
$*$ & $*$ \\
$*$ & $*$ & $*$ \\
$*$ & $*$
\end{tabular}

* 总芯.

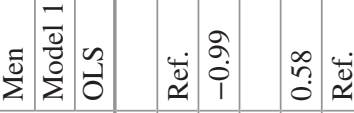

을 을

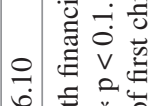

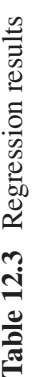

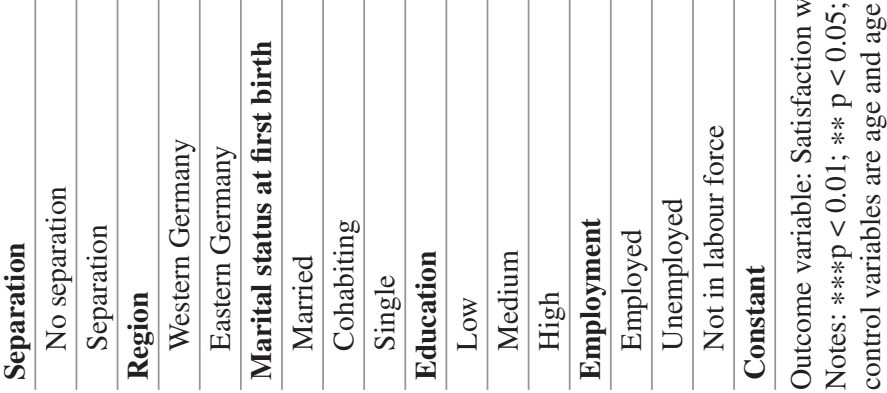


time-constant traits of the separated fathers, explain much of the decline in satisfaction with the financial situation after separation. The overall pattern for women is similar. In this case as well, western German respondents who were highly educated and employed reported being more satisfied with their financial situation. However, the parameter for separation is stable and highly significant across all models. The fixed-effects model shows that a separation is associated with a decline in satisfaction with the financial situation of 0.67 units. Thus, the drop in satisfaction among women cannot be explained by changes in employment patterns around the time of the divorce, or by unobserved characteristics that select people into separation. There must be other unobserved factors (such as a drop in household income or low alimony payments) that explain the decline in mothers' economic well-being.

The models above analysed men and women separately, which makes it difficult to compare the parameters for men and women across models. In order to better compare the effect sizes for both genders, we pool the male and the female sample in a final step. We estimate an OLS-model, and include an interaction variable for gender and separation in the model. Instead of a simple dummy variable for separation, we include time since separation. This approach allows us to examine gender differences in the recovery of well-being following separation. The model results are displayed as average predicted values. Figure 12.2 shows the results for satisfaction with family life. We find that fathers experienced a steeper decline in their satisfaction with family life after separation than mothers, which is in line with previous research (Huß and Pollmann-Schult 2018; Leopold 2018; Leopold and Kalmijn 2016). A comparison of non-separated fathers and fathers in the first 2 years after

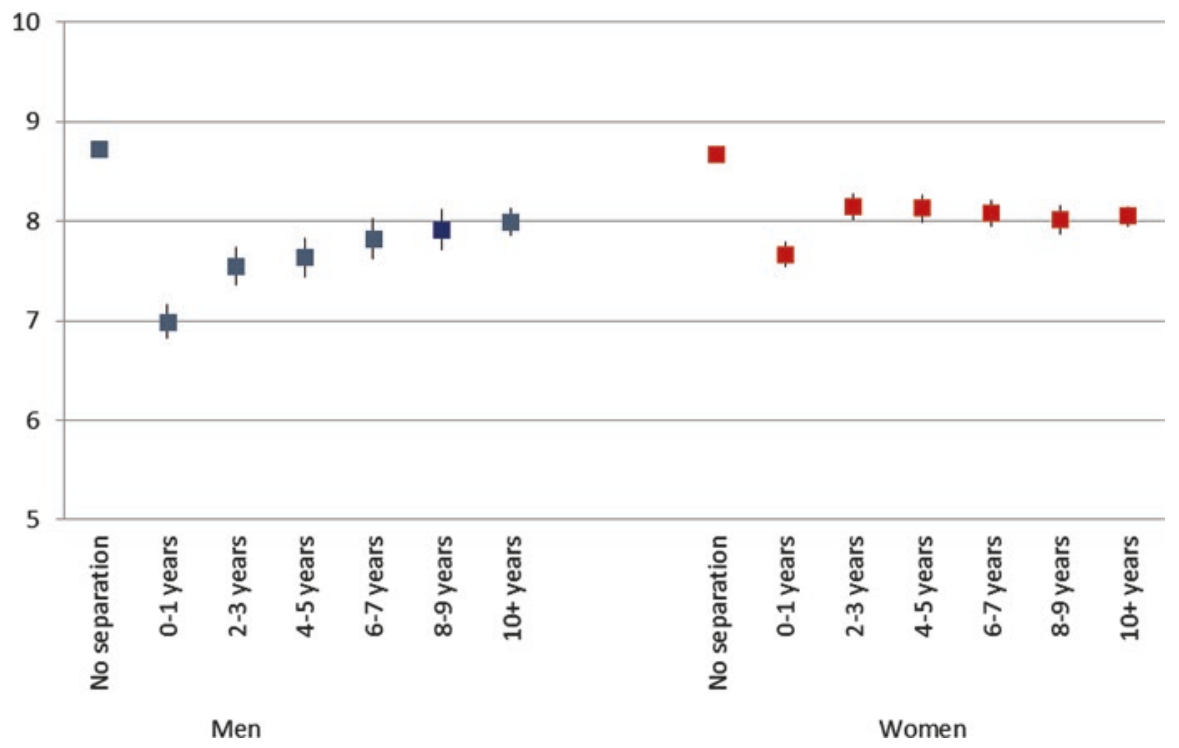

Fig. 12.2 Linear predictions from OLS-regression and 95\%-confidence interval. Outcome variable: satisfaction with family life (scale $0-10$ )

Notes: Further covariates in the model are: region (East/West), education, employment, age, age of first child, marital status at first birth 


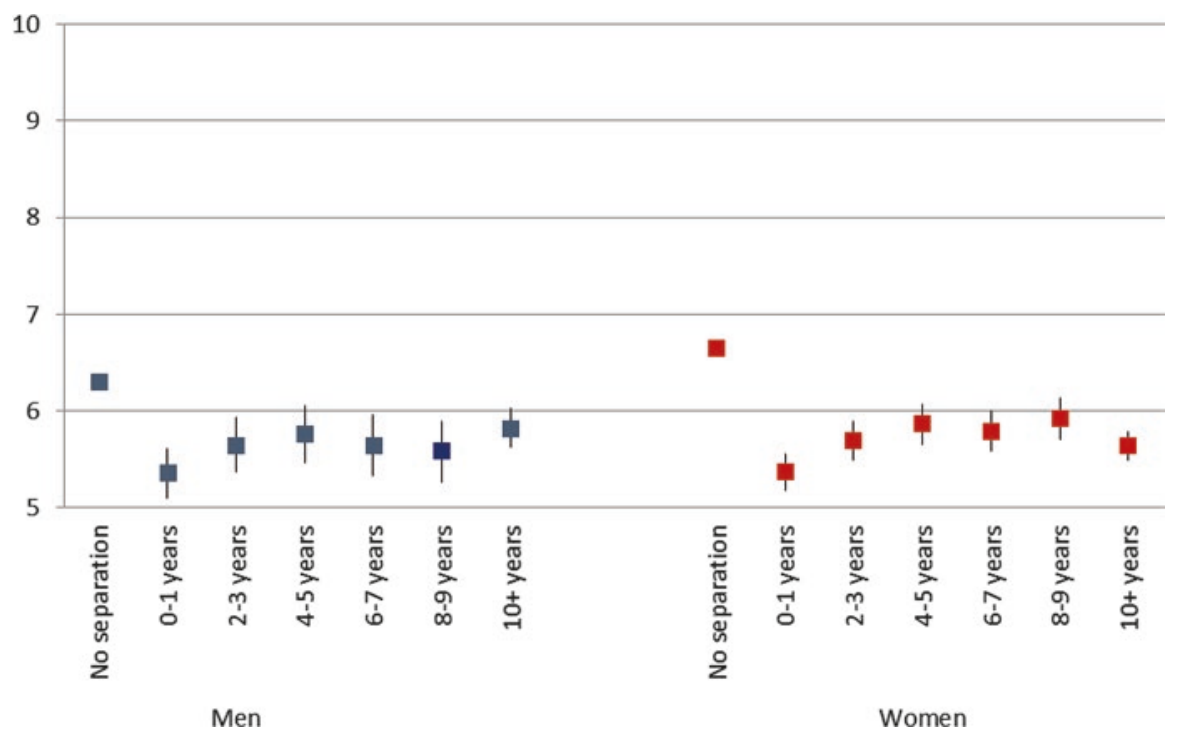

Fig. 12.3 Linear predictions from OLS-regression and 95\%-confidence interval. Outcome variable: satisfaction with financial situation (scale $0-10$ )

Notes: Further covariates in the model are: region (East/West), education, employment, age, age of first child, marital status at first birth

separation indicates that separated fathers' satisfaction with family life declined by almost two units. The corresponding value for mothers was one unit. The results also show that although the decline was more severe for fathers, the family satisfaction levels of fathers recovered more quickly than those of mothers. The findings for the financial situation (Fig. 12.3) show the opposite pattern. Here, we see that the financial satisfaction levels of women decreased more than those of men following separation. This observation is generally in line with previous research that has shown that mothers experience a more drastic reduction in their household income after separation than fathers (Bröckel and Andreß 2015). However, compared to these previous findings, the gender differences in satisfaction with the household's financial situation seem to be more modest than the gender differences in the (equivalent) household income.

\section{Satisfaction with Family Life and the Financial Situation After Separation}

Table 12.4 reports the results for the models that examine separated parents' satisfaction with family life. We expected to find that practising shared parenting increased the family-related well-being of separated fathers. Our investigation does not support this hypothesis. Model 1 suggests that the level of satisfaction with 
family life of resident fathers was 0.50 units higher than that of non-resident fathers, but that there was hardly any difference in family satisfaction levels between nonresident fathers and fathers who practise shared parenting. Model 2, which controls for socio-economic confounders, further suggests that there was no relationship between where the children lived and fathers' satisfaction with family life, as resident and non-resident fathers did not differ after controlling for major confounders. The model results indicate, however, that cohabitation with or marriage to a new partner increased the fathers' satisfaction with family life. The fixed-effects model (Model 3) supports this finding, and additionally suggests that having a new child played a decisive role in fathers' satisfaction with family life. As fathers commonly do not live with their children from prior partnerships, a new child may have another meaning for fathers than for mothers.

The results for mothers reveal a similar pattern. However, Model 1 indicates that practising shared parenting had some positive and weakly significant impact on satisfaction with family life. The parameter was, however, not robust to the inclusion of further variables. Model 2, which controls for major socio-economic characteristics, shows no significant relationship between the parental arrangement and the level satisfaction with family life. In this case as well, having a cohabiting or married partner is shown to substantially increase satisfaction with family life. Unlike the model results for men, the model results for women indicate that the birth of a new child did not significantly affect their satisfaction levels. It might be more important for fathers than for mothers to support their idea of a "real" family. The outcomes of the fixed-effects model (Model 3) support the notion that there was no relationship between women's parenting arrangements and their levels of satisfaction with family life.

Table 12.5 reports the results for the parents' levels of satisfaction with their financial situation. The findings of Model 1 suggest that practising shared parenting positively influenced men's satisfaction with their financial situation. However, this association does not appear to be stable across the models. After the socio-economic confounders are included, the relationship between the residential arrangement and well-being disappears (Model 2). This pattern is also found in the model that includes the partnered parents as well (see Table 12.3): i.e., the results show that fathers who were married or cohabiting, were from western Germany, or were highly educated and employed were more satisfied with their financial situation than other fathers. The results of the fixed-effects model (Model 3) suggest that the birth of a new child was associated with lower levels of satisfaction with the financial situation.

We had speculated that shared parenting would have affected the well-being of mothers in particular. Again, we have to reject our hypothesis, as we do not find any association between the parenting arrangement and mothers' satisfaction with their financial situation, even before controlling for the socio-economic characteristics (Model 1). The results of Model 2 indicate that being unemployed or non-employed had a very large negative effect on women's satisfaction with their financial situation. We also find that mothers who were cohabiting or had married a new partner reported higher levels of satisfaction with their financial situation than single 


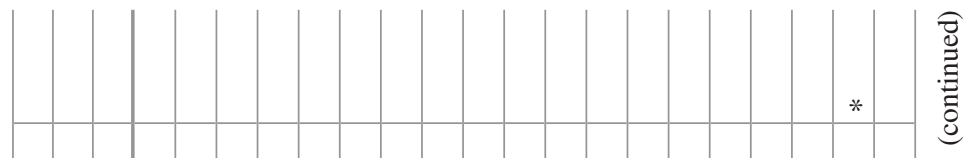

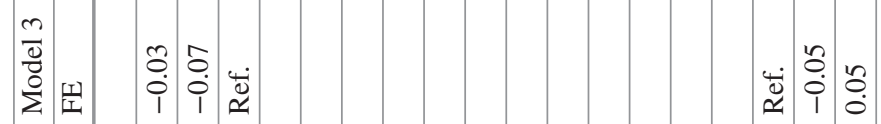

$*$ *

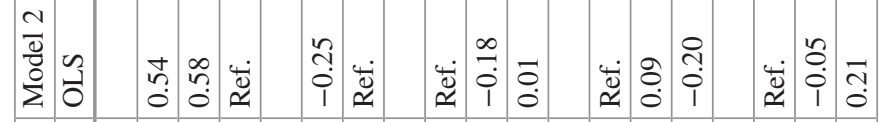

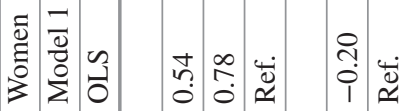

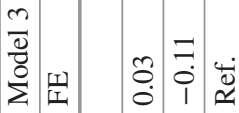

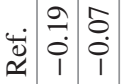

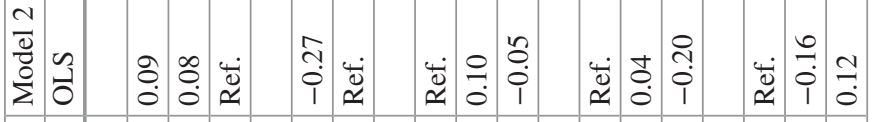
*

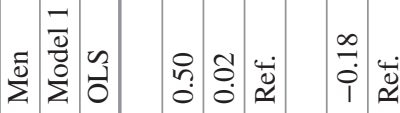

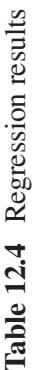

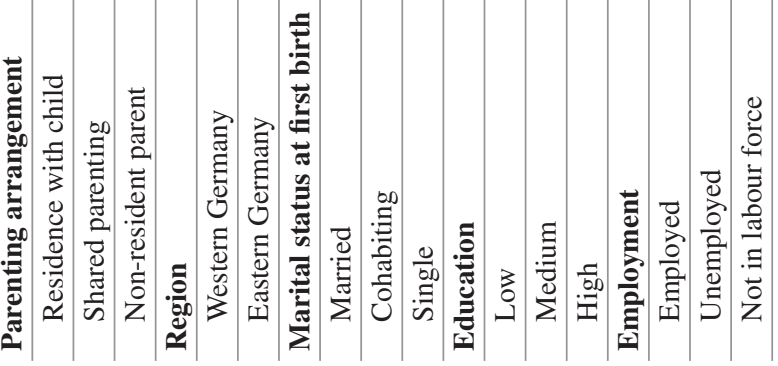




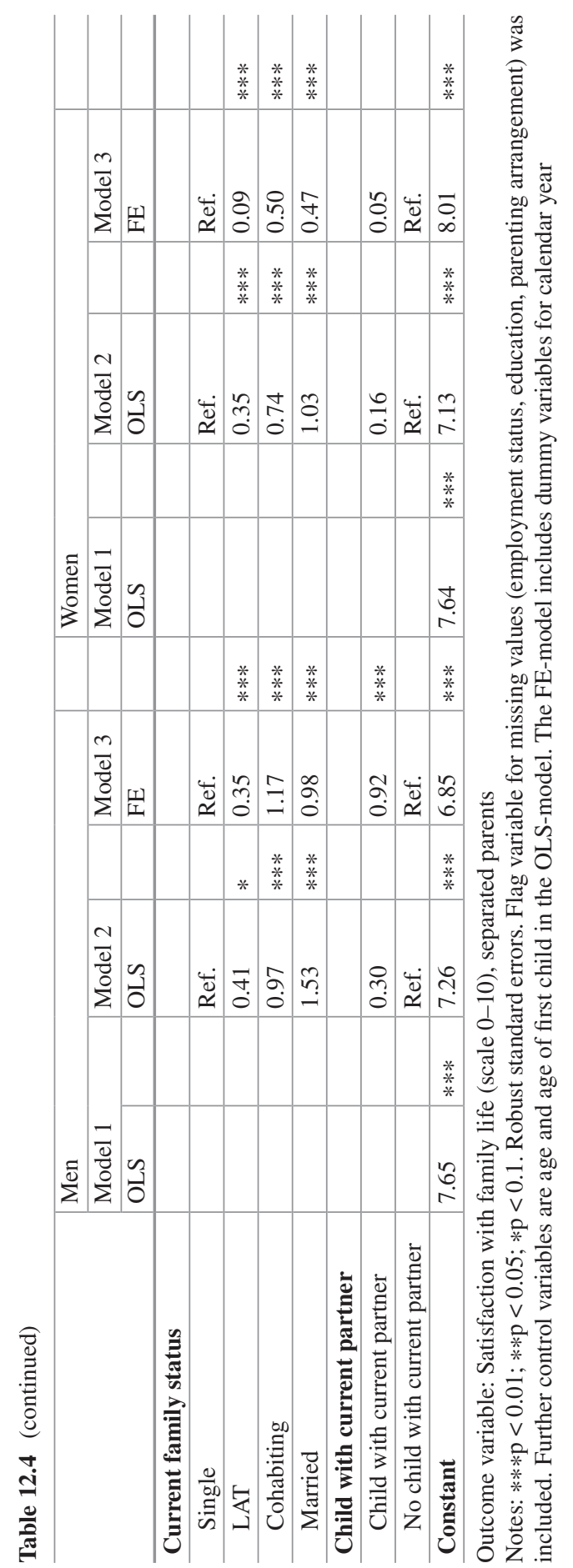




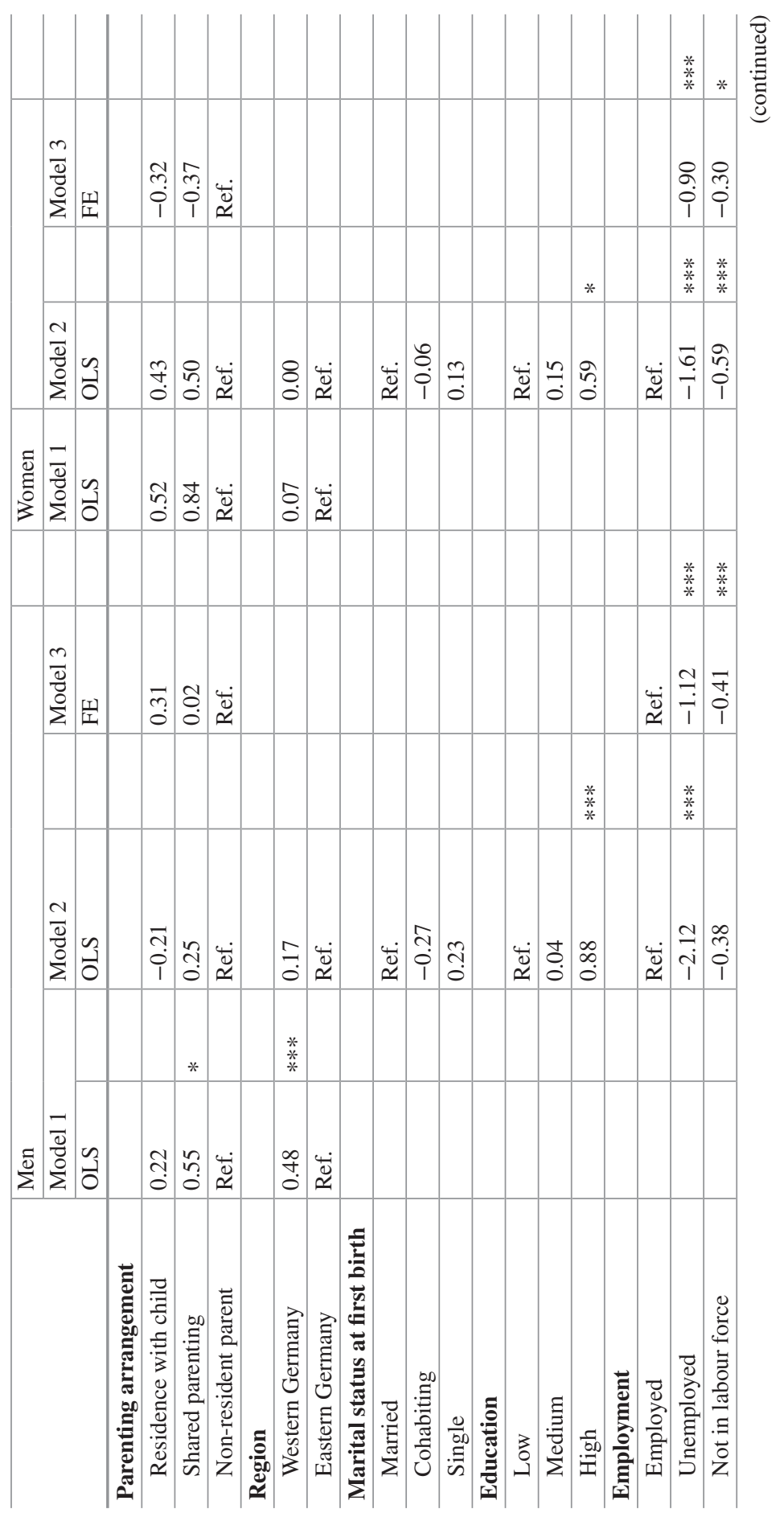




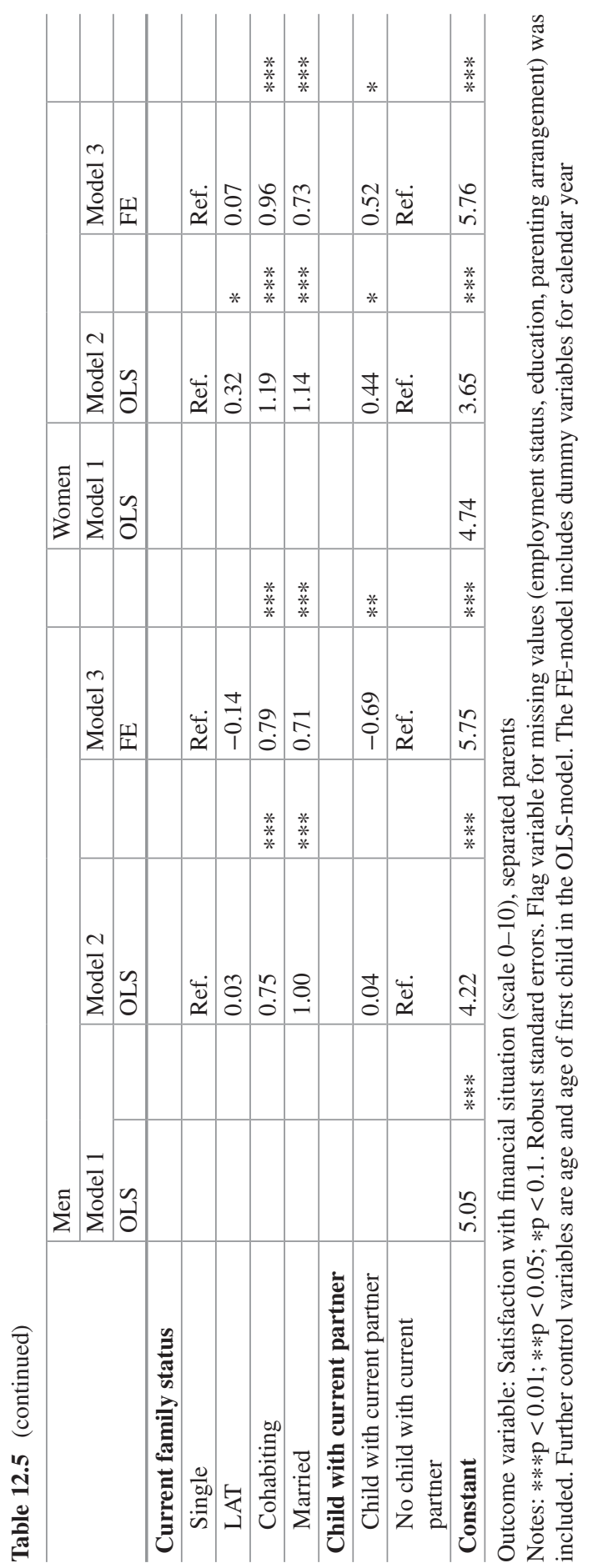


mothers. Unlike among men, the birth of a new child is not shown to affect levels of satisfaction with the household's financial situation among women. The results of the fixed-effects model support this finding (Model 3).

\section{Discussion}

In this chapter, we have examined parental well-being after separation. The analysis was based on data from the German Family panel (pairfam) spanning a total of 10 years. We argued that mothers and fathers face "gendered realities" after union dissolution. As children commonly live with their mother after their parents split up, separated fathers tend to be negatively affected by having reduced contact with their offspring. Conversely, separated women often face a rapid drop in their (equivalent) household income, especially if they had not been previously employed or had been working part-time only. Against this background, we assumed that men would report a strong decline in their levels of satisfaction with family life, while mothers would report reduced levels of satisfaction with their financial situation. The results of our investigation support these assumptions. We found that men's satisfaction with family life decreased by about one unit after separation; and that women also experienced a deterioration in family well-being, but that the effect was less pronounced among women than among men. The pattern we observed for satisfaction with the household's financial situation was reversed, with women experiencing a more rapid decline in satisfaction than men. These results were largely robust to different model specifications, with the exception of our findings for men's financial well-being. After several major socio-economic characteristics were included in the model, the effect size declined. Furthermore, the fixed-effects model showed no significant effects of separation. Thus, it appears that much of the correlation was due to particular kinds of fathers (i.e., fathers with low wages or other characteristics that would cause them to be concerned about their finances) who selected themselves into separation.

In addition to investigating the effects of separation on parents' levels of satisfaction with their family life and financial situation, we looked at how practising shared parenting affected their well-being. Our findings indicated that practising shared parenting was only weakly correlated with parental well-being. After socioeconomic variables were included in the model, no significant association could be detected. Instead, we found that cohabiting with or having married a new partner was the decisive determinant of the well-being of separated parents. The results also showed that for men, having had another child increased their family well-being, but reduced their financial well-being. Financial well-being was also found to be strongly associated with employment status, as being unemployed or non-employed reduced the well-being of both men and women to a similar extent.

Like in other European countries, shared parenting is becoming increasingly common in Germany. While shared legal custody has been the default legal custody arrangement for divorced parents in Germany since 1998, the question of whether 
(equally) shared parenting should be made the default physical custody arrangement after separation is now being debated. The current discussion has primarily focused on the question of how shared parenting affects the well-being of children, while paying little attention to the impact of shared parenting on the well-being of parents. Our study adds to this debate by showing that practising shared parenting neither positively nor negatively affects parental well-being. One potential explanation for this rather unexpected "non-finding" is the heterogeneity of the parents who practise shared parenting. On the one hand, parents who practise shared parenting must maintain a cooperative relationship, which may be positively associated with well-being. On the other hand, these parents are forced to interact with their expartner. Depending on the level of conflict between the ex-partners and their ability to co-parent, this pressure to engage with each other may be a source of stress that reduces their well-being.

This study has several limitations. Most importantly, there is no common legal definition of shared parenting in the social sciences. The lack of a clear concept has resulted in radically different operational definitions and values for shared parenting being reported in different studies. In the German case, for example, estimates of the percentage of separated parents who practice shared parenting range from 5\% to 15\% (Institut für Demoskopie Allensbach 2017). In this study, we have defined shared parenting as an arrangement in which the child lives with both of his/her parents, or in which the non-resident parent sees the child every day. Using this definition, we found that $12 \%$ of separated parents were practising shared parenting in Germany, which is in line with the abovementioned prior estimates. Even though our findings are stable across different operational definitions of shared parenting, the discussion of shared parenting and its effect on children and parents is greatly hampered by the lack of a shared understanding of the concept.

Our analyses were very much focused on determining the causal influence of shared parenting on well-being. While the fixed-effect analysis was able to account for unobserved time-invariant characteristics, including variables that depict the gendered realities before separation would have been desirable. In particular, it would have been intriguing to explore how the parents' division of work before they separated affected their arrangements after they separated, and how this association, in turn, affected the well-being of fathers and mothers. It is possible that having experienced a more egalitarian division of paid and unpaid labour before they separated was beneficial for the well-being of the parents (Kessler 2018). If, for example, the mother was more engaged in paid employment while the father was more engaged in childcare and housework before the separation, the reduction in the mother's household income might have been less dramatic, and a more equal parenting arrangement might have emerged. Both of these factors might have increased either the financial or family well-being. Moreover, prior research has shown that the quality of the relationship between the ex-partners is decisive for the success of their parenting arrangements and for their well-being after separation (Cornelißen and Monz 2016; Markham et al. 2017). Although information of this kind is surveyed in the German Family Panel, there are currently too few cases in the dataset to allow us to investigate this issue. Finally, a drawback that we share with other 
studies that examine the behaviour and well-being of separated parents is selective panel attrition, which is a particular problem for the sample of separated fathers (Müller and Castiglioni 2015).

Acknowledgments The research leading to these results received funding from the German Research Foundation (project number: 266395921). This chapter uses data from the German Family Panel pairfam, coordinated by Josef Brüderl, Sonja Drobnič, Karsten Hank, Bernhard Nauck, Franz Neyer, and Sabine Walper. pairfam is funded as long-term project by the German Research Foundation (DFG).

\section{Appendix}

Table 12.6 Sample composition, all parents, person-years by column percent

\begin{tabular}{c|l|l|l|l|l|l}
\hline & \multicolumn{3}{|l|}{$\begin{array}{l}\text { Satisfaction with family } \\
\text { life }\end{array}$} & \multicolumn{4}{l}{$\begin{array}{l}\text { Satisfaction with financial } \\
\text { situation }\end{array}$} \\
\cline { 2 - 7 } & Men & Women & Total & Men & Women & Total \\
\hline Gender & & & & & & \\
\hline Male & - & - & 0.40 & - & - & 0.40 \\
\hline Female & - & - & 0.60 & - & - & 0.60 \\
\hline Region & & & & & & \\
\hline Western Germany & 0.64 & 0.67 & 0.66 & 0.64 & 0.67 & 0.66 \\
\hline Eastern Germany & 0.36 & 0.33 & 0.34 & 0.36 & 0.33 & 0.34 \\
\hline Duration since separation & & & & & & \\
\hline No separation & 0.80 & 0.73 & 0.76 & 0.81 & 0.74 & 0.76 \\
\hline 0-1 years after separation & 0.03 & 0.04 & 0.04 & 0.03 & 0.04 & 0.04 \\
\hline 2-3 years after separation & 0.03 & 0.04 & 0.03 & 0.03 & 0.04 & 0.03 \\
\hline 4-5 years after separation & 0.03 & 0.04 & 0.03 & 0.03 & 0.03 & 0.03 \\
\hline 6-7 years after separation & 0.02 & 0.04 & 0.03 & 0.02 & 0.03 & 0.03 \\
\hline 8-9 years after separation & 0.03 & 0.03 & 0.03 & 0.02 & 0.03 & 0.03 \\
\hline 10 or more years after separation & 0.06 & 0.08 & 0.08 & 0.06 & 0.08 & 0.08 \\
\hline Education & & & & & & \\
\hline Low & 0.09 & 0.11 & 0.10 & 0.08 & 0.11 & 0.10 \\
\hline Medium & 0.54 & 0.58 & 0.56 & 0.54 & 0.57 & 0.56 \\
\hline High & 0.37 & 0.31 & 0.34 & 0.38 & 0.32 & 0.34 \\
\hline Employment status & & & & & & \\
\hline Employed & 0.90 & 0.65 & 0.75 & 0.90 & 0.68 & 0.77 \\
\hline Unemployed & 0.05 & 0.05 & 0.05 & 0.05 & 0.05 & 0.05 \\
\hline Not in labour force & 0.05 & 0.29 & 0.19 & 0.05 & 0.26 & 0.18 \\
\hline Missing & 0.00 & 0.01 & 0.01 & 0.00 & 0.01 & 0.01 \\
\hline Family status at first birth & & & & & & \\
\hline Married & 0.54 & 0.55 & 0.54 & 0.54 & 0.55 & 0.54 \\
\hline Cohabiting & 0.35 & 0.32 & 0.33 & 0.36 & 0.32 & 0.34 \\
\hline Single & 0.11 & 0.13 & 0.13 & 0.10 & 0.13 & 0.12 \\
\hline & & & & & & \\
\hline & & & & & & \\
\hline
\end{tabular}


Table 12.6 (continued)

\begin{tabular}{|c|c|c|c|c|c|c|}
\hline & \multicolumn{3}{|c|}{$\begin{array}{l}\text { Satisfaction with family } \\
\text { life }\end{array}$} & \multicolumn{3}{|c|}{$\begin{array}{l}\text { Satisfaction with financial } \\
\text { situation }\end{array}$} \\
\hline & Men & Women & Total & Men & Women & Total \\
\hline \multicolumn{7}{|l|}{ Current family status } \\
\hline Single & 0.07 & 0.10 & 0.09 & 0.07 & 0.10 & 0.09 \\
\hline LAT & 0.03 & 0.06 & 0.05 & 0.03 & 0.06 & 0.05 \\
\hline Cohabiting & 0.17 & 0.16 & 0.16 & 0.17 & 0.15 & 0.16 \\
\hline Married & 0.73 & 0.68 & 0.70 & 0.73 & 0.68 & 0.70 \\
\hline \multicolumn{7}{|l|}{ Child with current partner } \\
\hline Child with current partner & 0.54 & 0.53 & 0.54 & 0.55 & 0.54 & 0.54 \\
\hline No child with current partner & 0.46 & 0.47 & 0.46 & 0.45 & 0.46 & 0.46 \\
\hline \multicolumn{7}{|l|}{ Parenting arrangement } \\
\hline Residence with child & 0.82 & 0.95 & 0.90 & 0.82 & 0.94 & 0.90 \\
\hline Shared parenting & 0.04 & 0.03 & 0.04 & 0.05 & 0.04 & 0.04 \\
\hline Non-resident parent & 0.12 & 0.01 & 0.05 & 0.11 & 0.01 & 0.05 \\
\hline Other & 0.02 & 0.01 & 0.01 & 0.02 & 0.01 & 0.01 \\
\hline \multicolumn{7}{|c|}{$\begin{array}{l}\text { Continuous covariates (Mean, std. } \\
\text { error) }\end{array}$} \\
\hline Age (Mean) & 36.72 & 35.39 & 35.92 & 37.19 & 35.87 & 36.39 \\
\hline Age (std. error) & $(0.05)$ & $(0.04)$ & $(0.03)$ & $(0.06)$ & $(0.05)$ & $(0.04)$ \\
\hline Age of child (Mean) & 7.65 & 8.37 & 8.09 & 7.82 & 8.59 & 8.29 \\
\hline Age of child (std. error) & $(0.05)$ & $(0.04)$ & $(0.03)$ & $(0.05)$ & $(0.04)$ & $(0.03)$ \\
\hline Satisfaction (Mean) & 8.48 & 8.52 & 8.51 & 6.28 & 6.33 & 6.31 \\
\hline Satisfaction (std. error) & $(0.02)$ & $(0.01)$ & $(0.01)$ & $(0.02)$ & $(0.02)$ & $(0.02)$ \\
\hline \multicolumn{7}{|l|}{ Sample size } \\
\hline Subjects & 2351 & 3425 & 5776 & 1886 & 2716 & 4602 \\
\hline Person years & 10,768 & 16,422 & 27,190 & 10,768 & 16,422 & 22,535 \\
\hline
\end{tabular}

Notes: Unweighted values

\section{References}

Allison, P. D. (2009). Fixed effects regression models. Los Angeles: Sage.

Amato, P. R., \& Rezac, S. J. (1994). Contact with nonresident parents, interparental conflict, and children's behavior. Journal of Family Issues, 15(2), 191-207. https://doi.org/10.117 7/0192513X94015002003.

Andreß, H.-J., \& Bröckel, M. (2007). Income and life satisfaction after marital disruption in Germany. Journal of Marriage and Family, 69(2), 500-512. https://doi. org/10.1111/j.1741-3737.2007.00379.x.

Bastin, S. (2016). Partnerschaftsverläufe alleinerziehender Mütter: Eine quantitative Untersuchung auf Basis des Beziehungs- und Familienpanels. [Repartnering of single mothers: A quantitative study based on the German Family Panel]. Wiesbaden: Springer VS.

Bauserman, R. (2002). Child adjustment in joint-custody versus sole-custody arrangements: A meta-analytic review. Journal of Family Psychology, 16(1), 91-102. https://doi. org/10.1037/0893-3200.16.1.91. 
Bayaz-Ozturk, G., Burkhauser, R. V., Couch, K. A., \& Hauser, R. (2018). The effects of union dissolution on the economic resources of man and women: A comparative analysis of Germany and the United States, 1985-2013. The Annals of the American Academy of Political and Social Science, 680(1), 235-258. https://doi.org/10.1177/0002716218793608.

Beckmeyer, J. J., Coleman, M., \& Ganong, L. H. (2014). Postdivorce coparenting typologies and children's adjustment. Family Relations, 63(4), 526-537. https://doi.org/10.1111/fare.12086.

Bergström, M., Fransson, E., Modin, B., Berlin, M., Gustafsson, P. A., \& Hjern, A. (2015). Fifty moves a year: Is there an association between joint physical custody and psychosomatic problems in children? Journal of Epidemiology and Community Health, 69(8), 769-774. https://doi. org/10.1136/jech-2014-205058.

Biotteau, A.-L., Bonnet, C., \& Cambois, E. (2019). Risk of major depressive episodes after separation: The gender-specific contribution of the income and support lost through union dissolution. European Journal of Population, 35(3), 519-542. https://doi.org/10.1007/s10680-018-9488-y.

Braver, S. L., \& Votruba, A. M. (2018). Does joint physical custody "cause" children's better outcomes? Journal of Divorce and Remarriage, 59(5), 452-468. https://doi.org/10.1080/1050255 6.2018 .1454203 .

Bröckel, M., \& Andreß, H.-J. (2015). The economic consequences of divorce in Germany: What has changed since the turn of the millennium? Comparative Population Studies, 40(3), 277-312. https://doi.org/10.12765/CPoS-2015-04en.

Brüderl, J., Drobnič, S., Hank, K., Nauck, B., Neyer, F. J., Walper, S., et al. (2019). The German Family Panel (pairfam). GESIS Data Archive, Cologne. ZA5678 Data file Version 10.0.0. https://doi.org/10.4232/pairfam.5678.10.0.0.

Bujard, M. (2015). Kinderlosigkeit in Deutschland: Wie interagieren Bildung, Wohnort, Migrationshintergrund, Erwerbstätigkeit und Kohorte? [Childlessness in Germany: How do education, place or residence, migration background, occupation, and cohort interact?]. Zeitschrift für Familienforschung/Journal of Family Research, 27(3), 270-296. https://doi. org/10.3224/zff.v27i3.21275.

Clark, A. E., Diener, E., Georgellis, Y., \& Lucas, R. E. (2008). Lags and leads in life satisfaction: A test of the baseline hypothesis. The Economic Journal, 118(529), F222-F243. https://doi. org/10.1111/j.1468-0297.2008.02150.x.

Cornelißen, W., \& Monz, A. (2016). Coparenting: Wie kooperieren Eltern in Bezug auf die Versorgung, Betreuung und Erziehung ihrer Kinder nach einer Trennung? Vier Fallbeispiele. [Co-parenting: How do parents cooperate after separation regarding their children's provisioning, care and education? Four case studies]. Zeitschrift für Soziologie der Erziehung und Sozialisation, 36(1), 23-38. https://doi.org/10.3262/ZSE1601023.

de Regt, S., Mortelmans, D., \& Marynissen, T. (2013). Financial consequences of relationship dissolution: A longitudinal comparison of formerly married and unmarried cohabiting men and women. Sociology, 47(1), 90-108. https://doi.org/10.1177/0038038512453793.

Dethloff, N. (2015). From separation to stepfamily. A legal perspective. In U. Zartler, V. HeintzMartin, \& O. Arránz Becker (Eds.), Family dynamics after separation: A life course perspective on post-divorce families (Vol. Special Issue/Sonderheft 10 der Zeitschrift für Familienforschung/ Journal of Family Research, pp. 205-218). Opladen/Berlin/Toronto: Barbara Budrich.

Dethloff, N., \& Kaesling, K. (2018). Kindesunterhalt und Wechselmodell - Eine vergleichende Perspektive. [Child support and shared parenting - A comparative perspective]. FamRZ, 2, 73-78.

Diener, E. (2009). Subjective well-being. In E. Diener (Ed.), The science of well-being: Social indicators research series (pp. 11-58). Dordrecht: Springer. https://doi. org/10.1007/978-90-481-2350-6_2.

Ferrer-i-Carbonell, A., \& Frijters, P. (2004). How important is methodology for the estimates of the determinants of happiness? The Economic Journal, 114(497), 641-659. https://doi. org/10.1111/j.1468-0297.2004.00235.x. 
Geisler, E., \& Kreyenfeld, M. (2019). Why do lone mothers fare worse than lone fathers? Lone parenthood and welfare benefit receipt in Germany. Comparative Population Studies, 44(2019), 61-84. https://doi.org/10.12765/CPoS-2019-09en.

Goldscheider, F., Bernhardt, E., \& Lappegård, T. (2015). The gender revolution: A framework for understanding changing family and demographic behavior. Population and Development Review, 41(2), 207-239. https://doi.org/10.1111/j.1728-4457.2015.00045.x.

Grätz, M. (2017). Does separation really lead fathers and mothers to be less involved in their children's lives? European Sociological Review, 33(4), 551-562. https://doi.org/10.1093/ esr/jex058.

Härkönen, J., Bernardi, F., \& Boertien, D. (2017). Family dynamics and child outcomes: An overview of research and open questions. European Journal of Population, 33(2), 163-184. https:// doi.org/10.1007/s10680-017-9424-6.

Henneman, H. (2017). Das Wechselmodell als Umgangsregelung - eine überzeugende Lösung? [Shared parenting as a physical custody arrangement - A convincing solution?]. NJW, 70(25), $1787-1790$.

Huinink, J., Brüderl, J., Nauck, B., Walper, S., Castiglioni, L., \& Feldhaus, M. (2011). Panel analysis of intimate relationships and family dynamics (pairfam): Conceptual framework and design. Zeitschrift für Familienforschung, 23(1), 77-101.

Huß, B., \& Pollmann-Schult, M. (2018). Lebenszufriedenheit von getrennt lebenden Müttern und Vätern [Life satisfaction of separated mothers and fathers]. Berlin/Rostock/Magdeburg. https:// doi.org/10.25673/5206.

Institut für Demoskopie Allensbach. (2017). Getrennt gemeinsam erziehen: Kernergebnisse einer Befragung von Trennungseltern [Joint parenting despite separation: Main results of a survey among separated parents]. Allensbach. https://www.ifd-allensbach.de/uploads/tx_studies/ Abach_Trennungseltern_Bericht.pdf. Accessed 26 Aug 2019.

Ivanova, K., \& Balbo, N. (2019). Cementing the stepfamily? Biological and stepparents' relationship satisfaction after the birth of a common child in stepfamilies. Journal of Family Issues, 40(10), 1346-1363. https://doi.org/10.1177/0192513X19836456.

Ivanova, K., Kalmijn, M., \& Uunk, W. (2013). The effect of children on men's and women's chances of re-partnering in a European context. European Journal of Population, 49(4), 417-444. https://doi.org/10.1007/s10680-013-9294-5.

Joyner, K., Peters, H. E., Hynes, K., Sikora, A., Taber, J., \& Rendall, M. (2012). The quality of male fertility data in major U.S. surveys. Demography, 49(1), 101-124. https://doi.org/10.1007/ s13524-011-0073-9.

Kalmijn, M. (2016). Father-child contact, interparental conflict, and depressive symptoms among children of divorced parents. European Sociological Review, 32(1), 68-80. https://doi. org/10.1093/esr/jcv095.

Kessler, D. (2018). The consequences of divorce for mothers and fathers: Unequal but converging? (LIVES Working Paper 71). Lausanne: https://doi.org/10.12682/lives.2296-1658.2018.71.

Kindler, H., \& Walper, S. (2016). Das Wechselmodell im Kontext elterlicher Konflikte. [Shared parenting in the context of parental conflicts]. Neue Zeitschrift für Familienrecht, 3(18), 820-824.

Kreyenfeld, M., Huinink, J., Trappe, H., \& Walke, R. (2012). DemoDiff: A dataset for the study of family change in eastern (and western) Germany. Schmollers Jahrbuch, 132(4), 653-660. https://doi.org/10.3790/schm.132.4.653.

Lee, D., \& McLanahan, S. (2015). Family structure transitions and child development: Instability, selection, and population heterogeneity. American Sociological Review, 80(4), 738-763. https://doi.org/10.1177/0003122415592129.

Leopold, T. (2018). Gender differences in the consequences of divorce: A study of multiple outcomes. Demography, 55(3), 769-797. https://doi.org/10.1007/s13524-018-0667-6.

Leopold, T., \& Kalmijn, M. (2016). Is divorce more painful when couples have children? Evidence from long-term panel data on multiple domains of well-being. Demography, 53(6), 1717-1742. https://doi.org/10.1007/s13524-016-0518-2. 
Lettmaier, S., \& Dürbeck, W. (2019). Die Behandlung elterlicher Umgangskosten im Unterhalts-, Sozial- und Steuerrecht. [Treatment of costs of parent-child contact in the legal regulations concerning maintenance, social rights and taxes]. FamRZ, 2, 81-88.

Lucas, R. E. (2007). Adaptation and the set-point model of subjective well-being: Does happiness change after major life events? Current Directions in Psychological Science, 16(2), 75-79. https://doi.org/10.1111/j.1467-8721.2007.00479.x.

Markham, M. S., Hartenstein, J. L., Mitchell, Y. T., \& Aljayyousi-Khalil, G. (2017). Communication among parents who share physical custody after divorce or separation. Journal of Family Issues, 38(10), 1414-1442. https://doi.org/10.1177/0192513X15616848.

McLanahan, S., Tach, L., \& Schneider, D. (2013). The causal effects of father absence. Annual Review of Sociology, 39(1), 399-427. https://doi.org/10.1146/annurev-soc-071312-145704.

Müller, B., \& Castiglioni, L. (2015). Stable relationships, stable participation? The effects of partnership dissolution and changes in relationship stability on attrition in a relationship and family panel. Survey Research Methods, 9(3), 205-219. https://doi.org/10.18148/srm/2016. v10i1.6207.

Nielsen, L. (2018). Joint versus sole physical custody: Children's outcomes independent of parentchild relationships, income, and conflict in 60 studies. Journal of Divorce and Remarriage, 59(4), 247-281. https://doi.org/10.1080/10502556.2018.1454204.

Poortman, A.-R. (2018). Postdivorce parent-child contact and child well-being: The importance of predivorce parental involvement. Journal of Marriage and Family, 80(3), 671-683. https:// doi.org/10.1111/jomf.12474.

Popova, D., \& Navicke, J. (2019). The probability of poverty for mothers after childbirth and divorce in Europe: The role of social stratification and tax-benefit policies. Social Science Research, 78(1), 57-70. https://doi.org/10.1016/j.ssresearch.2018.10.007.

Ruetten, B. (2016). Das paritätische Wechselmodell und Streitfragen des Kindergeldes sowie anderer kindbezogener Leistungen. [Equally shared parenting and the controversial issue of child allowance and other child related benefits]. Neue Zeitschrift für Familienrecht, 8, 337-341.

Schnor, C. (2014). The contexts of partnership and childbearing as determinants of union stability: A quantitative analysis on western and eastern German partnerships with data from the German Family Panel. Rostock: Max Planck Institute for Demographic Research. https:// www.demogr.mpg.de/en/projects_publications/publications_1904/dissertations/the_contexts_ of_partnership_and_childbearing_as_determinants_of_union_stability_a_quantitative_5344. htm. Accessed 26 Aug 2019.

Schumann, E. (2018). Gemeinsam getragene Elternverantwortung nach Trennung und Scheidung -Reformbedarf im Sorge-, Umgangs- und Unterhaltsrecht? [Joint parental responsibility after separation and divorce - Reform need of legal regulations concerning custody, contact, and maintenance?]. München: C.H. Beck.

Smyth, B. M. (2017). Special issue on shared-time parenting after separation. Family Court Review, 55(4), 494-499. https://doi.org/10.1111/fcre.12299.

Sodermans, A., Botterman, S., Havermans, N., \& Matthijs, K. (2015). Involved fathers, liberated mothers? Joint physical custody and the subjective well-being of divorced parents. Social Indicators Research, 122(1), 257-277. https://doi.org/10.1007/s11205-014-0676-9.

Soons, J. P. M., Liefbroer, A. C., \& Kalmijn, M. (2009). The long-term consequences of relationship formation for subjective well-being. Journal of Marriage and Family, 71(5), 1254-1270. https://doi.org/10.1111/j.1741-3737.2009.00667.x.

Statistisches Bundesamt. (2018a). Bevölkerung und Erwerbstätigkeit. Statistik der rechtskräftigen Beschlüsse in Eheaufösungssachen (Scheidungsstatistik) und Statistik der Aufhebung von Lebenspartnerschaften (Berichtsjahr: 2016) [Population and employment. Statistic on divorce and statistic on the dissolution of civil unions]. Wiesbaden: Statistisches Bundesamt.

Statistisches Bundesamt. (2018b). Alleinerziehende in Deutschland 2017. Begleitmaterial zur Pressekonferenz am 2. August 2018 [Lone parents in Germany 2017. Accompanying information with a press conference on August 2nd, 2018]. Wiesbaden: Statistisches Bundesamt. 
Steinbach, A. (2019). Children's and parents' well-being in joint physical custody: A literature review. Family Process, 58(2), 353-369. https://doi.org/10.1111/famp.12372.

Sünderhauf, H. (2013). Wechselmodell: Psychologie-Recht-Praxis: Abwechselnde Kinderbetreuung durch Eltern nach Trennung und Scheidung [Joint physical custody: Psychology-law-practice: Alternate parental child care after separation and divorce]. Wiesbaden: Springer.

Thielemans, G., \& Mortelmans, D. (2019). Female labour force participation after divorce: How employment histories matter. Journal of Family and Economic Issues, 40(2), 180-193. https:// doi.org/10.1007/s10834-018-9600-9.

van Damme, M., Kalmijn, M., \& Uunk, W. (2009). The employment of separated women in Europe: Individual and institutional determinants. European Sociological Review, 25(2), 183-197. https://doi.org/10.1093/esr/jcn042.

van der Heijden, F., Gähler, M., \& Härkönen, J. (2015). Are parents with shared residence happier? Children's postdivorce residence arrangements and parents' life satisfaction. Stockholm Research Reports in Demography, 17(2015).

van der Heijden, F., Poortman, A.-R., \& van der Lippe, T. (2016). Children's postdivorce residence arrangements and parental experienced time pressure. Journal of Marriage and Family, 78(2), 468-481. https://doi.org/10.1111/jomf.12283.

Walper, S. (2016). Arrangements elterlicher Fürsorge nach Trennung und Scheidung: Das Wechselmodell im Licht neuer Daten aus Deutschland. [Arrangements of parental custody after separation and divorce: Joint physical custody in light of new data from Germany]. In Deutscher Familiengerichtstag (Ed.), 21. Deutscher Familiengerichtstag vom 21. bis 24. Oktober 2015 in Brühl (Vol. Brühler Schriften zum Familienrecht, Band 19, pp. 99-143). Bielefeld: Gieseking Verlag.

Walper, S., \& Beckh, K. (2006). Adolescents' development in high-conflict and separated families: Evidence from a German longitudinal study. In A. Clarke-Stewart \& J. Dunn (Eds.), Families count: Effects on child and adolescent development (pp. 238-270). Cambridge: Cambridge University Press.

Walper, S., Thönnissen, C., \& Alt, P. (2015). Effects of family structure and the experience of parental separation: A focus on adolescents' well-being. Comparative Population Studies-Zeitschrift für Bevölkerungsforschung, 40(3), 335-364. https://doi.org/10.12765/CPoS-2015-12en.

Yuan, A. S. V. (2016). Father-child relationships and nonresident fathers' psychological distress: What helps and what hurts? Journal of Family Issues, 37(5), 603-621. https://doi.org/10.117 7/0192513X14526394.

Open Access This chapter is licensed under the terms of the Creative Commons Attribution 4.0 International License (http://creativecommons.org/licenses/by/4.0/), which permits use, sharing, adaptation, distribution and reproduction in any medium or format, as long as you give appropriate credit to the original author(s) and the source, provide a link to the Creative Commons license and indicate if changes were made.

The images or other third party material in this chapter are included in the chapter's Creative Commons license, unless indicated otherwise in a credit line to the material. If material is not included in the chapter's Creative Commons license and your intended use is not permitted by statutory regulation or exceeds the permitted use, you will need to obtain permission directly from the copyright holder. 